\title{
Characterization of Three Extracellular $\beta$-Glucosidases Produced by a Fungal Isolate Aspergillus sp. YDJ14 and Their Hydrolyzing Activity for a Flavone Glycoside
}

\author{
Jong Min $\mathrm{Oh}^{1}$, Jae Pil Lee ${ }^{1}$, Seung Cheol Baek ${ }^{1}$, Yang Do $\mathrm{Jo}^{2}$, and Hoon Kim ${ }^{1,2 *}$ \\ ${ }^{1}$ Department of Pharmacy, and Research Institute of Life Pharmaceutical Sciences, Sunchon National University, Suncheon 57922, Republic \\ of Korea \\ ${ }^{2}$ Department of Agricultural Chemistry, Sunchon National University, Suncheon 57922, Republic of Korea
}

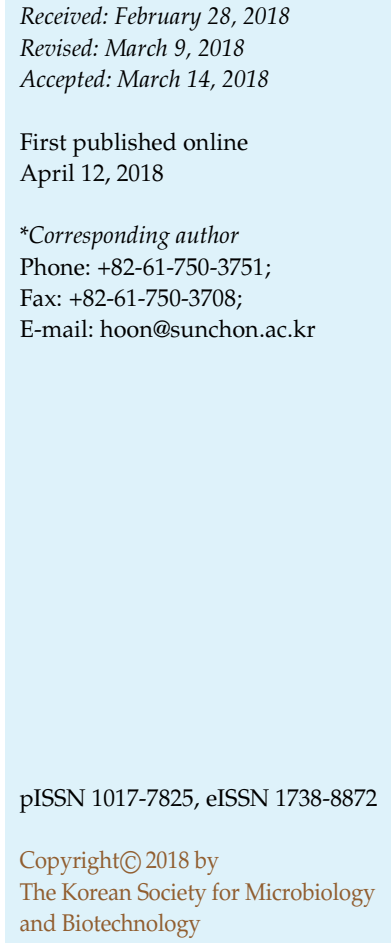

A cellulolytic fungus, YDJ14, was isolated from compost and identified as an Aspergillus sp. strain. Three extracellular $\beta$-glucosidases, BGL-A1, BGL-A2, and BGL-A3, were separated using ultrafiltration, ammonium sulfate fractionation, and High-Q chromatography. The molecular masses of the three enzymes were estimated to be 100,45 , and $40 \mathrm{kDa}$, respectively, by SDS-PAGE. The optimum $\mathrm{pH}$ and temperature of BGL-A3 were 5.0 and $50^{\circ} \mathrm{C}$, respectively, whereas the optimum $\mathrm{pH}$ and temperature of BGL-A1 and BGL-A2 were identical ( 4.0 and $60^{\circ} \mathrm{C}$, respectively). The half-life of BGL-A3 at $70^{\circ} \mathrm{C}$ (2.8 $\left.\mathrm{min}\right)$ was shorter than that of BGL-A1 and BGL-A2 (12.1 and $8.8 \mathrm{~min}$, respectively). All three enzymes preferred $p$-nitrophenyl- $\beta$-Dglucopyranoside $(p \mathrm{NPG})$ and hardly hydrolyzed cellobiose, suggesting that these enzymes were aryl $\beta$-glucosidases. The $K_{\mathrm{m}}$ of BGL-A3 $(1.26 \mathrm{mM})$ for $p$ NPG was much higher than that of BGL-A1 and BGL-A2 (0.25 and $0.27 \mathrm{mM}$, respectively). These results suggested that BGL-A1 and BGL-A2 were similar in their enzymatic properties, whereas BGL-A3 differed from the two enzymes. When tilianin (a flavone glycoside of acacetin) was reacted with the three enzymes, the inhibitory activity for monoamine oxidase, a target in the treatment of neurological disorders, was similar to that shown by acacetin. We conclude that these enzymes may be useful in the hydrolysis of flavone glycosides to improve their inhibitory activities.

Keywords: Aspergillus sp. YDJ14, extracellular $\beta$-glucosidases, aryl $\beta$-glucosidases, flavone glycoside hydrolysis

\section{Introduction}

$\beta$-Glucosidases (E.C. 3.2.1.21) catalyze the hydrolysis of $\beta-1,4$-glycosidic linkages to release nonreducing terminal glucosyl residues from disaccharides, oligosaccharides, and alkyl or aryl $\beta$-glucosides $[1,2]$. According to their substrate specificity, enzymes are divided into three groups: (i) aryl $\beta$-glucosidases, which hydrolyze only aryl $\beta$-glucosidic linkages; (ii) cellobiases, which hydrolyze cellobiose; and (iii) broad-substrate specificity $\beta$-glucosidases, which hydrolyze a wide range of substrates with different bonds $[3,4]$. Most of the $\beta$-glucosidases are broad specificity $\beta$-glucosidases [2].

Fungal $\beta$-glucosidases are used in bioflavorings and in the development production of novel carbohydrate foods, animal feeds, bioethanol, and pharmaceuticals [4-6]. They are also employed in the hydrolysis of isoflavone glycosides [7]. Recently, fungal $\beta$-glucosidase from several Aspergillus species, including A. fumigatus [8], A. saccharolyticus [9], A. niger [10], A. ochraceus [11], A. oryzae [12], A. terreus [13], and Aspergillus sp. [15], have been characterized. The production of active $\beta$-glucosidases from microbial compost communities has also been studied [16].

Many researchers have studied the hydrolysis of flavonoid 
glycosides by $\beta$-glucosidases, with the majority of studies focusing on isoflavone glycosides from soybean [17-19], and flavanone glycosides from citrus extracts [20]. However, little information is available on flavone glycosides.

Previous research demonstrated that acacetin, a flavonoid, was a potent inhibitor of monoamine oxidases (MAOs), catalyzing the oxidative deamination of monoamine neurotransmitters and serving as a target for the treatment for neurological disorders [21]. The same study showed that the inhibitory activity of tilianin, a glycoside of acacetin, was lower than that of acacetin.

In this report, three $\beta$-glucosidases were separated from Aspergillus sp. YDJ14, a cellulolytic fungal strain isolated from compost, and their biochemical properties were characterized. The potential applications of these $\beta$-glucosidases in the hydrolysis of flavone glycosides and in improving the inhibitory activity of a pharmaceutical enzyme were also investigated.

\section{Materials and Methods}

\section{Chemicals and Enzymes}

Glucose, cellobiose, xylobiose, $p$-nitrophenyl- $\beta$-D-glucopyranoside ( $p$ NPG), $p$-nitrophenyl- $\beta$-D-cellobioside ( $p$ NPC), $p$-nitrophenyl- $\beta$ D-xylopyranoside ( $p$ NPX), 4-methylumbelliferyl- $\beta$-D-glucopyranoside (MUG), carboxymethyl-cellulose (CMC), barley $\beta$-glucan, birchwood xylan, dinitrosalicylic acid (DNS), trypan blue, and other chemicals were purchased from Sigma-Aldrich (USA). Acacetin and tilianin (acacetin 7-glucoside) were isolated from Agastache rugosa, and MAO inhibition was assayed using recombinant human MAO-A, as described previously [21].

\section{Isolation and Identification of the Fungal Strain}

A compost sample was obtained from the Compost Factory [22], and cellulolytic fungi were isolated on PDA (potato dextrose agar) plates containing $0.4 \% \mathrm{CMC}$ (PDA/CMC) or xylan (PDA/ xylan), as described previously [15]. Based on the halo size around the colony, a strain was selected and named YDJ14. The isolated strain was identified by $18 \mathrm{~S}$ rRNA sequencing by Solgent (Korea). Sequence similarity was searched, and a phylogenetic tree was constructed using the BLASTN program $[23,24]$ on the NCBI web site. The nucleotide sequence of the YDJ14 isolate was deposited in GenBank under the accession number MG976613.

\section{Enzyme Production and Isolation}

The isolate was cultured at $30^{\circ} \mathrm{C}$, with shaking at $150 \mathrm{rpm}$ in $200 \mathrm{ml}$ of potato dextrose broth, as described previously [15], with some modifications (i.e., 21 days of culture to analyze the extracellular $\beta$-glucosidase activity in the culture supernatant). The proteins were separated by ultrafiltration, ammonium sulfate fractionation (40-60\%), and High-Q column chromatography, as described previously [15]. The concentrations of protein were analyzed by the Bradford method [26]. Sodium dodecyl sulfatepolyacrylamide gel electrophoresis (SDS-PAGE) was carried out using $11.5 \%$ polyacrylamide gels [27].

\section{Activity Staining}

Activity staining for $\beta$-glucosidase activity in active High-Q chromatography fractions was performed in a gel after SDS-PAGE and renaturation, as previously described, except for the use of MUG instead of MUC $[15,28]$.

\section{Enzyme Assay}

The activity of $\beta$-glucosidase was assayed in a reaction mixture of $2 \mathrm{mM} p \mathrm{NPG}$ in $50 \mathrm{mM}$ sodium citrate buffer ( $\mathrm{pH}$ 5.0) as substrate, with the reaction at $50^{\circ} \mathrm{C}$ stopped after $30 \mathrm{~min}$ [15]. One unit of $\beta$-glucosidase activity was defined as the amount of enzyme that generated $1 \mu \mathrm{mol}$ of $p$-nitrophenol in $1 \mathrm{~min}$. Substrate specificity was analyzed using $0.2 \mathrm{mM} p \mathrm{NPG}, p \mathrm{NPC}, p \mathrm{NPX}$, cellobiose, and xylobiose as small substrates, and 0.5\% CMC, $\beta$-glucan, and xylan as polysaccharides. The substrates $p \mathrm{NPG}$, $p$ NPC and $p$ NPX were analyzed by measuring the amounts of $p$-nitrophenol released. The others were analyzed by measuring the amounts of reducing sugar released using the DNS method [29]. One unit of enzyme activity was defined as the amount of enzyme that liberated $1 \mu \mathrm{mol}$ of reducing sugar per minute under the conditions as above.

\section{Biochemical Characterization of the Purified Enzyme}

The optimum $\mathrm{pH}$ for enzyme activity was analyzed using $50 \mathrm{mM}$ universal buffer (from $\mathrm{pH} 3.0$ to 8.0 ), and the optimum temperature was determined from $30^{\circ} \mathrm{C}$ to $80^{\circ} \mathrm{C}$ in $50 \mathrm{mM}$ of sodium citrate buffer ( $\mathrm{pH}$ 5.0). Thermostability was analyzed by preincubation of the enzyme without substrate for up to $1 \mathrm{~h}$ at $60^{\circ} \mathrm{C}$ or $70^{\circ} \mathrm{C}$. The effects of various cations $\left(\mathrm{Na}^{+}, \mathrm{K}^{+}, \mathrm{Ca}^{2+}, \mathrm{Mg}^{2+}\right.$, $\mathrm{Mn}^{2+}, \mathrm{Zn}^{2+}, \mathrm{Fe}^{2+}, \mathrm{Cu}^{2+}, \mathrm{Co}^{2+}$, and $\mathrm{Ba}^{2+}$ ) at $2.0 \mathrm{mM}$, and $10 \%$ isopropanol, $1 \%$ Triton $\mathrm{X}-100$, and $1 \%$ SDS on enzyme activity were determined. The $K_{\mathrm{m}}$ and $V_{\max }$ values for the enzymes were determined using Lineweaver-Burk plots at five concentrations of $p$ NPG $(0.1-4.5 \mathrm{mM})$ at $50^{\circ} \mathrm{C}$.

\section{Binding Analysis with Insoluble Avicel}

The binding properties of the enzymes to carbohydrate were analyzed as described previously, with slight modifications [30]. Briefly, the crude extract was mixed with $1.5 \%$ Avicel in $0.3 \mathrm{ml}$ of $50 \mathrm{mM}$ sodium citrate buffer, $\mathrm{pH}$ 5.0, by shaking for $40 \mathrm{~min}$ on ice. The mixtures were then centrifuged. The amount of unbound enzyme was determined by measuring the cellulase activity in the supernatant.

\footnotetext{
Hydrolysis of a Flavone Glycoside and Analysis of MAO-A Inhibitory Activity

Tilianin $(100 \mu \mathrm{M})$, a flavone glycoside, was reacted for $6 \mathrm{~h}$ at $50^{\circ} \mathrm{C}$ with approximately $0.1 \mathrm{U}$ of each $\beta$-glucosidase in $50 \mu \mathrm{l}$ of
} 


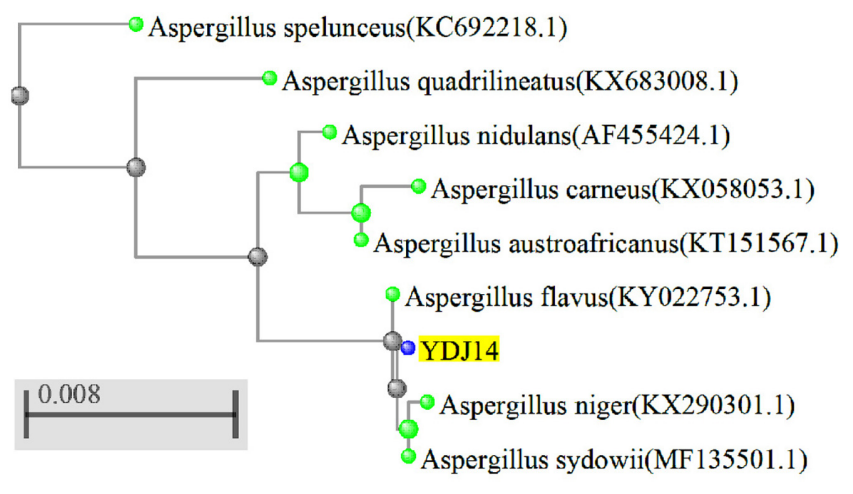

Fig. 1. Phylogenetic tree of the strain YDJ14.

$0.1 \mathrm{M}$ sodium phosphate buffer ( $\mathrm{pH}$ 6.0) [15]. After boiling for $5 \mathrm{~min}$ and centrifugation, the supernatant was added to $450 \mu \mathrm{l}$ of MAO-A assay mixture in $0.1 \mathrm{M}$ sodium phosphate, $\mathrm{pH} 7.4$, making $10 \mu \mathrm{M}$ of tilianin, and the absorbance was measured at $316 \mathrm{~nm}$, as described previously [21]. At the same time, the absorbances of a control containing MAO-A only, an inhibitory control containing MAO-A and $10 \mu \mathrm{M}$ of acacetin or tilianin, and incubated inhibitory controls (MAO-A and each flavone, and $\beta$-glucosidase but not reacted) were measured.

\section{Results}

\section{Isolation of Fungal Strains}

When the sample was grown on PDA/CMC or PDA/ xylan, four isolates showed both CMC- and xylandegrading activities. The isolate showing the largest halo on the plate was selected and named YDJ14. The 18S rRNA sequence of the YDJ14 isolate showed 99\% similarity with many other Aspergillus sp. strains, such as A. flavus (KY022753.1), A. niger (KX290301.1), A. sydowii (MF135501.1), and $A$. nidulans (AF455424.1), and showed 98\% similarity with A. carneus (KX058053.1) and A. austroafricanus (KT151567.1) in the NCBI server. A phylogenetic tree was constructed, as illustrated in Fig. 1. The isolate was named Aspergillus sp. YDJ14.

\section{Production and Separation of $\beta$-Glucosidases}

The Aspergillus sp. YDJ14 isolate produced the maximum amount of $\beta$-glucosidase at 21 days after inoculation. When the culture supernatant was concentrated to approximately 20 -fold, the yield was $85.3 \%$ (Table 1 ). High-Q chromatography of the ammonium sulfate fractionate showed major (fractions from 36 to 40) and minor (fractions from 46 to 48) activity peaks (Fig. 2A). In SDS-PAGE analysis, the fractions in the major peak exhibited two kinds of protein bands at each side of the maximum peak (fraction 38); a protein band from fraction $37(100 \mathrm{kDa})$ and a protein band from fraction $40(45 \mathrm{kDa})$. The protein band from fraction 47 in the minor peak was $40 \mathrm{kDa}$ (left of Fig. 2B). The three enzymes were named BGL-A1, BGL-A2, and BGL-A3. Zymogram analysis of the fractions following activity staining using MUG after SDS-PAGE and renaturation revealed an active band that matched that of BGL-A3, whereas BGL-A1 and BGL-A2 did not produce active bands (right of Fig. 2B). The molecular mass of this band corresponded to $40 \mathrm{kDa}$. When the MUG-hydrolyzing activity was measured in a liquid-type assay, the intensity of BGL-A1 was greater than that of BGL-A2 and BGL-A3, which was contrary to expectations, based on the results of activity staining on the gel (Fig. 2C).

\section{Characterization of the $\beta$-Glucosidases}

The optimum $\mathrm{pH}$ values of BGL-A1 and BGL-A2 were identical ( $\mathrm{pH}$ 4.0). The optimum $\mathrm{pH}$ of BGL-A3 was $\mathrm{pH}$ 5.0. The optimum temperatures of BGL-A1 and BGL-A2 were also identical $\left(60^{\circ} \mathrm{C}\right)$, whereas that of BGL-A3 was $50^{\circ} \mathrm{C}$. In the thermostability experiments, BGL-A3 was almost inactivated after $30 \mathrm{~min}$ at $70^{\circ} \mathrm{C}$, whereas BGL-A1 and BGL-A2 remained stable, with more than $70 \%$ of residual

Table 1. Separation of three extracellular $\beta$-glucosidases from Aspergillus sp. YDJ14.

\begin{tabular}{|c|c|c|c|c|c|c|c|}
\hline Procedure & $\begin{array}{l}\text { Fraction } \\
\text { number }\end{array}$ & $\begin{array}{l}\text { Volume } \\
\text { (ml) }\end{array}$ & $\begin{array}{c}\text { Total } \\
\text { activity } \\
\text { (U) }\end{array}$ & $\begin{array}{c}\text { Total } \\
\text { protein } \\
(\mathrm{mg})\end{array}$ & $\begin{array}{l}\text { Specific } \\
\text { activity } \\
(\mathrm{U} / \mathrm{mg})\end{array}$ & $\begin{array}{l}\text { Purification } \\
\text { (fold) }\end{array}$ & $\begin{array}{c}\text { Yield } \\
(\%)\end{array}$ \\
\hline Culture supernatant & - & 326 & 253.3 & 15.29 & 16.6 & 1 & 100 \\
\hline Ultrafiltration & - & 16 & 216.0 & 3.65 & 59.2 & 3.57 & 85.3 \\
\hline$\left(\mathrm{NH}_{4}\right)_{2} \mathrm{SO}_{4}$ fractionate $(40-60 \%)$ & - & 1 & 63.9 & 1.50 & 42.6 & 2.57 & 25.2 \\
\hline \multirow{2}{*}{ High-Q chromatography } & $40(\mathrm{~A} 2)$ & 1 & 1.62 & 0.017 & 95.3 & 5.74 & 0.64 \\
\hline & 47 (A3) & 1 & 1.63 & 0.0084 & 194.0 & 11.7 & 0.64 \\
\hline
\end{tabular}



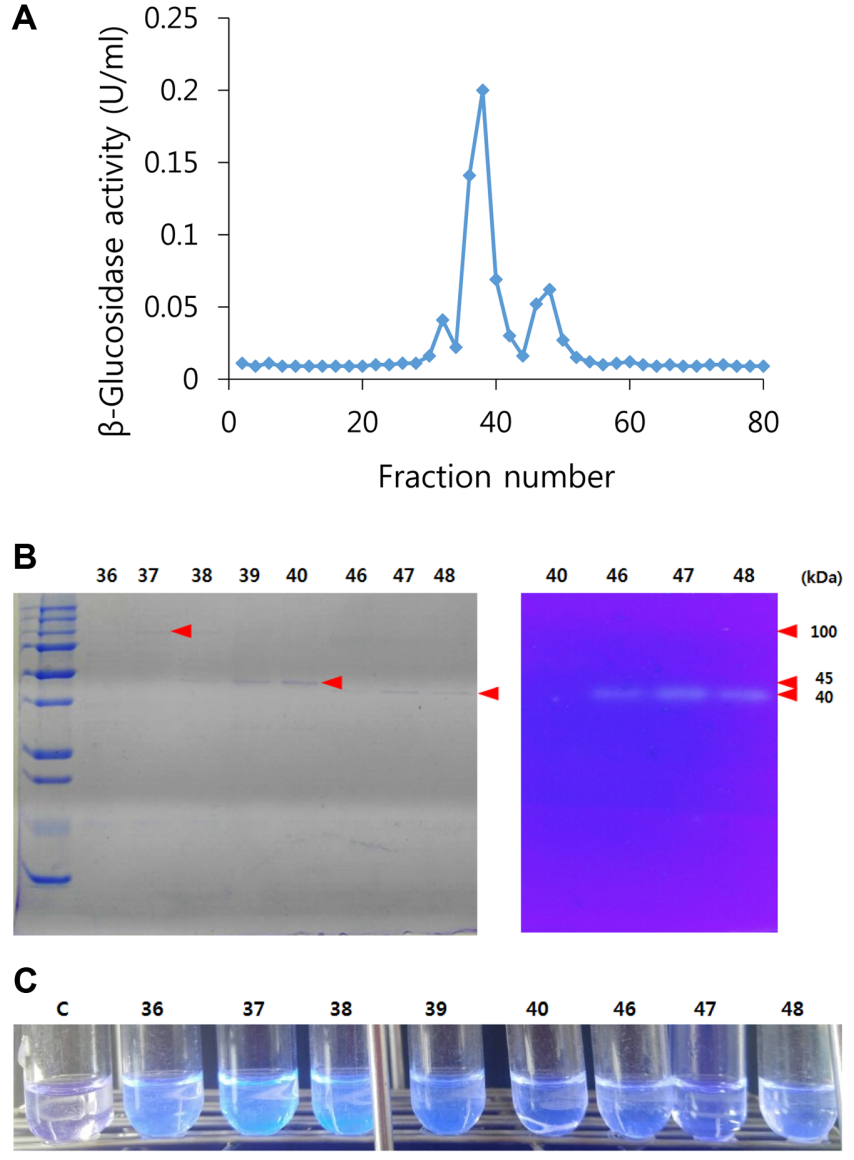

Fig. 2. Analysis of fractions eluted by High-Q chromatography. (A) Activity profile. (B) SDS-PAGE of active High-Q chromatography fractions (left) and a zymogram obtained after SDS-PAGE/ renaturation of the fractions (right). (C) Semi-quantitative MUGhydrolyzing activity assay of the fractions monitored photographically after a reaction with $1 \mathrm{mM}$ MUG for $10 \mathrm{~min}$ at $50^{\circ} \mathrm{C}$. The numbers on the tops of the figures represent the fractions obtained by High-Q chromatography.

activities. The half-life of BGL-A3 at $70^{\circ} \mathrm{C}(2.8 \mathrm{~min})$ was shorter than that of BGL-A1 and BGL-A2 (12.1 and $8.8 \mathrm{~min}$, respectively). The activities of BGL-A1, BGL-A2, and BGL-A3 were not affected significantly by the divalent ions at $2.0 \mathrm{mM}$ and $10 \%$ isopropanol, $1 \%$ Triton $\mathrm{X}-100$, and $1 \%$ SDS, but BGL-A3 was inhibited by $15.2 \%$ and $26.8 \%$ in the
Table 2. Substrate specificities of the three extracellular $\beta$-glucosidases isolated from Aspergillus sp. YDJ14

\begin{tabular}{lccc}
\hline & \multicolumn{3}{c}{ Relative activity (\%)* } \\
\cline { 2 - 4 }$p$ NPG & BGL-A1 & BGL-A2 & BGL-A3 \\
$p$ NPC & 100 & 100 & 100 \\
$p$ NPX & $0.08 \pm 0.01$ & nd & nd \\
Cellobiose & $0.4 \pm 0.01$ & $1.28 \pm 0.17$ & $0.49 \pm 0.34$ \\
$\beta$-Glucan & $0.88 \pm 0.14$ & $1.01 \pm 0.36$ & $0.47 \pm 0.70$ \\
CMC & nd & nd & nd \\
Xylan & nd & $0.14 \pm 0.091$ & nd \\
Xylobiose & nd & nd & nd \\
\hline
\end{tabular}

${ }^{*}$ Relative activities were calculated on the basis of the specific activities in $\mathrm{U} / \mathrm{mg}$ protein. Enzyme activities were analyzed using $0.2 \mathrm{mM} p \mathrm{NPG}, p \mathrm{NPC}, p \mathrm{NPX}$, xylobiose, and cellobiose owing to the high blank value. For polysaccharides, $0.5 \% \mathrm{CMC}, \beta$-glucan, and xylan were used. nd, not detectable.

presence of $\mathrm{Ba}^{2+}$ and SDS, respectively (data not shown).

Among the substrates tested, $p$ NPG was the most efficiently hydrolyzed by BGL-A1, BGL-A2, and BGL-A3 (Table 2). The hydrolyzing activities of the three enzymes for $p$ NPC, $p N P X$, xylobiose, and cellobiose were negligible or not detectable. The hydrolyzing activities for polysaccharides, such as $\beta$-glucan, CMC, and xylan were also negligible or not detectable.

Lineweaver-Burk plots for BGL-A1, BGL-A2, and BGL-A3 were linear (Fig. 3). The $K_{\mathrm{m}}$ values of BGL-A1 and BGL-A2 were similar $(0.25$ and $0.27 \mathrm{mM}$, respectively). In contrast, the $K_{\mathrm{m}}$ value of BGL-A3 $(1.26 \mathrm{mM})$ was approximately five times higher than that BGLA1and BGL-A2 (Table 3). The $V_{\max }$ of BGL-A1 $(131.0 \mathrm{U} / \mathrm{mg})$ was similar to that of BGL-A2 $(101.1 \mathrm{U} / \mathrm{mg})$ but lower than that of BGL-A3 $(213.5 \mathrm{U} / \mathrm{mg})$. The catalytic efficiency of BGL-A1 $(524.0 \mathrm{U} / \mathrm{mg} \cdot \mathrm{mM})$ expressed by $V_{\max } / K_{\mathrm{m}}$ was higher than that of BGL-A2 $(374.4 \mathrm{U} / \mathrm{mg} \cdot \mathrm{mM})$ and BGL-A3 $(169.4 \mathrm{U} / \mathrm{mg} \cdot \mathrm{mM})$.

\section{Binding Properties to Avicel}

To investigate the abilities of the three enzymes to bind to carbohydrate, the residual enzyme activities of the supernatants were measured after binding to Avicel. None

Table 3. Kinetic parameters of the three extracellular $\beta$-glucosidases from Aspergillus sp. YDJ14.

\begin{tabular}{cccc}
\hline & $K_{\mathrm{m}}(\mathrm{mM})$ & $V_{\max }(\mathrm{U} / \mathrm{mg}$ protein $)$ & $V_{\max } / K_{\mathrm{m}}\left(\mathrm{U} \mathrm{mg} \mathrm{protein}^{-1} \mathrm{mM}^{-1}\right)$ \\
\hline BGL-A1 & $0.25 \pm 0.030$ & $131.0 \pm 8.5$ & 524.0 \\
BGL-A2 & $0.27 \pm 0.067$ & $101.1 \pm 4.3$ & 374.4 \\
BGL-A3 & $1.26 \pm 0.001$ & $213.5 \pm 5.5$ & 169.4 \\
\hline
\end{tabular}

BGL-A1, BGL-A2, and BGL-A3 were assayed using fractions 36 (119.4 U/mg protein), 39 (91.8 U/mg protein), and 47 (194.0 U/mg protein), respectively. 
BGL-A1

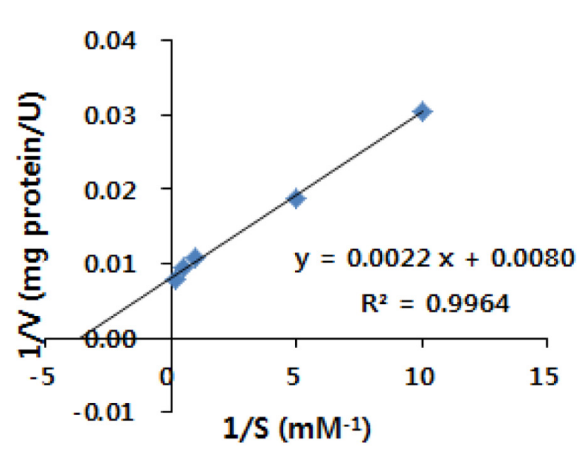

BGL-A2

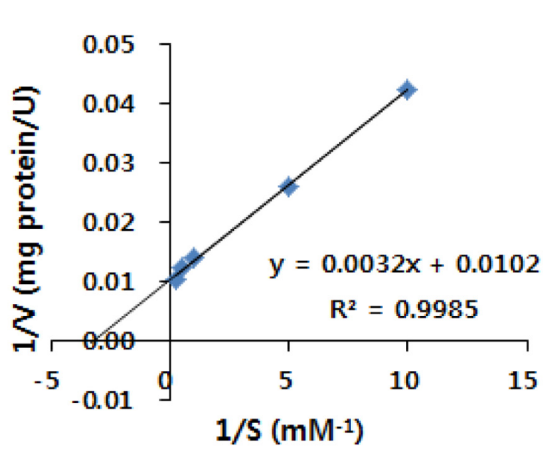

BGL-A3

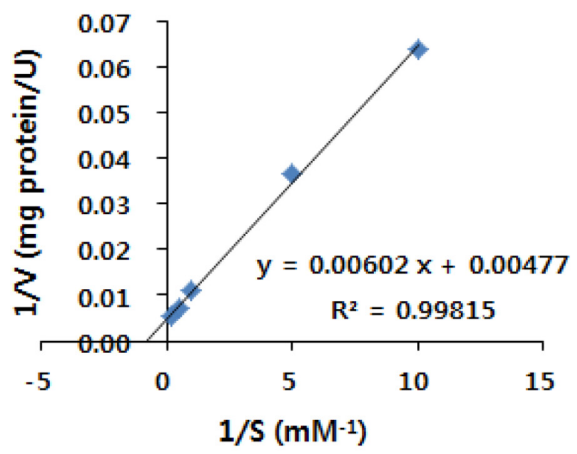

Fig. 3. Lineweaver-Burk plots of BGL-A1, BGL-A2, and BGL-A3.

of the enzymes bound to Avicel at a range of $95.4-103.3 \%$ (data not shown).

\section{Hydrolysis of a Flavone Glycoside and Analysis of MAO-A Inhibitory Activity}

When MAO-A was reacted in the presence of $10 \mu \mathrm{M}$ acacetin or tilianin, the residual activities were $3.5 \%$ or $90.7 \%$, respectively (Fig. 4). However, after tilianin was reacted with BGL-A1, BGL-A2, or BGL-A3, and the tilianin

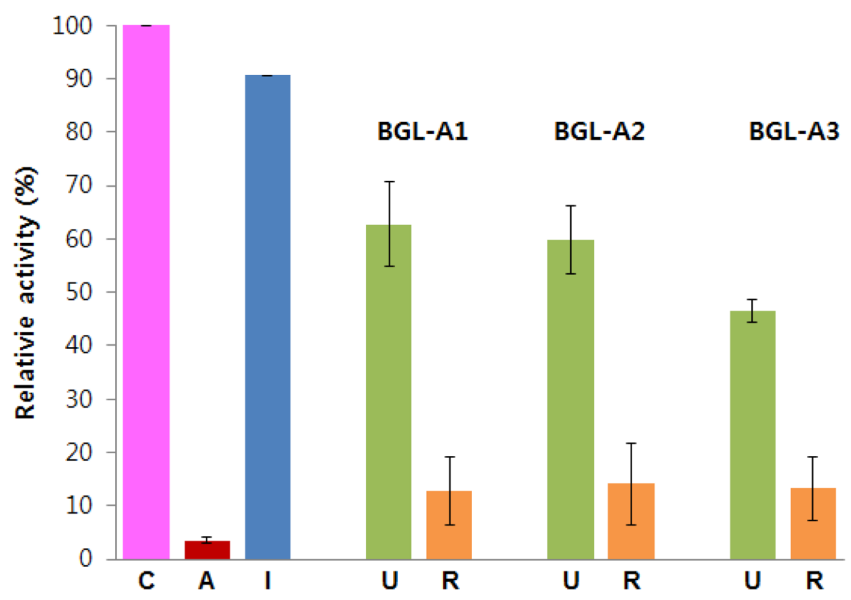

Fig. 4. Inhibition of MAO-A activity after reacting tilianin, a flavone glycoside, with BGL-A1, BGL-A2, and BGL-A3.

$\mathrm{C}$, Control containing only MAO-A; I, inhibitory control in the presence of tilianin $(10 \mu \mathrm{M}) ; \mathrm{U}$, unreacted controls containing tilianin and each enzyme (i.e., I + unreacted mixtures); R, reacted for $6 \mathrm{~h}$ at $50^{\circ} \mathrm{C}$ with each enzyme (i.e., I + reacted mixtures). The glycoside hydrolyzing mixture $(50 \mu \mathrm{l})$ contained a 10 times higher glycoside concentration ( $100 \mu \mathrm{M}$ of tilianin) than the working concentration in the MAO-A assay mixture and approximately $0.1 \mathrm{U}$ of each enzyme. After hydrolysis, each reacted mixture was added to the MAO-A assay mixtures $(450 \mu \mathrm{l})$ mixture was added to the MAO-A reaction mixtures, the residual activities of MAO-A decreased markedly to $12.8 \%$, $14.1 \%$, and $13.3 \%$, respectively, closely resembling the value obtained for acacetin (Fig. 4). In this experiment, the control containing enzyme but not reacted was included, because the two reaction buffers used for glycoside hydrolysis and the MAO-A assay were different. In the controls, activities decreased to $62.8 \%, 59.7 \%$, and $46.5 \%$, probably due to the presence of reactants in the hydrolyzed glycoside mixture. However, the activities of the controls were much higher than those after the hydrolysis reaction. These results strongly suggested that BGL-A1, BGL-A2, and BGL-A3 cleaved a glycosidic linkage in the flavone glycoside, yielding an aglycone flavonoid, acacetin.

\section{Discussion}

YDJ14 isolated from compost showed greater cellulolytic activity than other isolates on the PDA plate. Based on its $18 \mathrm{~S}$ rRNA sequence, YDJ14 was assigned to the Aspergillus genus and named Aspergillus sp. YDJ14. The Aspergillus sp. YDJ14 isolate grew more slowly and produced $\beta$ glucosidase later (after 21 days) than Aspergillus sp. YDJ216 (after 15 days) in shaking culture [15].

The proteins were separated by High-Q chromatography, and major and minor activity peaks were analyzed by SDSPAGE. SDS-PAGE of the major peak revealed two protein bands, which appeared in a gradient manner before and behind the maximum peak. The molecular masses of the proteins in fractions 37 and 40 corresponded to 100 (BGL-A1) and $45 \mathrm{kDa}$ (BGL-A2), respectively (Fig. 2B). The molecular mass of the protein in the minor peak corresponded to $40 \mathrm{kDa}$ (BGL-A3). In total, three $\beta$-glucosidase isoenzymes were separated from this strain. 
Molecular masses of extracellular $\beta$-glucosidases are diverse [6]. Similar to this Aspergillus sp. YDJ14 isolate, previous studies reported isoenzymes of $\beta$-glucosidase produced from several strains of Aspergillus species, including isozymes of approximately 78 and $43 \mathrm{kDa}$ from $A$. ochraceus MTCC 1810 [11]; 130, 120, and $100 \mathrm{kDa}$ from A. oryzae [12]; 125 and $50 \mathrm{kDa}$ from $A$. nidulans [31]; and 97 and $45 \mathrm{kDa}$ from Aspergillus sp. YDJ216 [15]. BGL-A3 is the smallest isozyme $(40 \mathrm{kDa})$ of the reported fungal $\beta$-glucosidases, close to that $(43 \mathrm{kDa})$ from $A$. ochraceus [11].

As shown by the zymogram analysis of fractions in the gel, BGL-A3 was active, suggesting that it may be more resistant to denaturation/renaturation than BGL-A1 and BGL-A2. However, contrary to this idea, the MUGhydrolyzing activity in a liquid assay of BGL-A1 was greater than that of BGL-A2 and BGL-A3. Although the reason for this finding is unclear, some factor(s) may possibly be lost or modified during SDS-PAGE and the denaturation/renaturation step [15].

In the present study, BGL-A1 and BGL-A2 had the same optimum $\mathrm{pH}$ (i.e., $\mathrm{pH} 4.0$ ), whereas the optimum $\mathrm{pH}$ of BGL-A3 was different (i.e., $\mathrm{pH}$ 5.0). These values are similar to those of most microbial $\beta$-glucosidases reported thus far [5]. The optimum temperature of BGL-A3 $\left(50^{\circ} \mathrm{C}\right)$ was different from that of BGL-A1 and BGL-A2 $\left(60^{\circ} \mathrm{C}\right)$, but similar to or higher than the temperatures reported for most other fungal $\beta$-glucosidases. The optimum temperature of BGL-A3 was lower than those $\left(65-70^{\circ} \mathrm{C}\right)$ of $A$. niger and A. terreus $\beta$-glucosidases, and those $\left(\sim 70^{\circ} \mathrm{C}\right)$ of $\beta$-glucosidases from other species, including Trichoderma reesei $[2,6]$.

BGL-A1, BGL-A2, and BGL-A3 showed absolute substrate specificity for $p$ NPG but negligible activities for other substrates, including cellobiose. This finding suggests BGLA1, BGL-A2, and BGL-A3 are typical aryl $\beta$-glucosidases, like those from A. sydowii BTMFS 55 [32], Neosartorya fischeri NRRL181 [33], Phialophora sp. G5 [34], and Aspergillus sp. YDJ216 [15]. The specificity of aryl $\beta$-glucosidases may be caused by their affinity for the aglycone moiety and their high electrophilicity, which would increase the stability of the intermediate generated during catalysis, as suggested by Plant et al. [35].

The $K_{\mathrm{m}}$ and $V_{\max }$ of BGL-A3 for $p$ NPG differed from those of BGL-A1 and BGL-A2. Among the three $\beta$-glucosidases, the specificity constant expressed by $V_{\max } / K_{\mathrm{m}}$ of BGL-A3 was the lowest. However, there was no difference in the binding properties of the three $\beta$-glucosidases to a carbohydrate, Avicel.

The antioxidant, anticancer, anti-hypercholesterolemia, anti-inflammatory, and antihypertensive activities of microbial $\beta$-glucosidases via hydrolysis of flavonoid glycosides have been investigated [4]. The hydrolysis of soybean isoflavones, ginsenosides, and geniposides by $\beta$-glucosidases from several strains, including $A$. terreus [13], Neosartorya fischeri [19], A. niger [14, 36], Neurospora crassa [37], Paecilomyces Bainier sp. 229 [38], and A. versicolor [39], have been reported.

However, little information is available on the improvement of inhibitory activity by glycoside hydrolysis against pharmaceutical enzymes, especially MAO. In this study, we investigated the hydrolysis of a flavone glycoside, tilianin, by BGL-A1, BGL-A2, and BGL-A3, and the subsequent effect on the inhibition of MAO-A activity. After hydrolyzing tilianin with the three $\beta$-glucosidases, MAO-A was significantly inhibited following the addition of the reacted mixtures. The hydrolysis and identification of the reaction products require further study. We suggest that the production of acacetin, which potently inhibits MAO-A $\left(\mathrm{IC}_{50}=0.19 \mu \mathrm{M}\right)$, may be responsible for the inhibitory activity against MAO-A, and that the three $\beta$-glucosidases from Aspergillus sp. YDJ14 efficiently cleave the glycosidic linkage of the flavone glycoside.

In this study, three extracellular $\beta$-glucosidases, BGL-A1, BGL-A2, and BGL-A3, were separated from Aspergillus sp. YDJ14. The molecular masses of BGL-A1, BGL-A2, and BGL-A3 were 100,45 , and $43 \mathrm{kDa}$, respectively, and all three enzymes were strict aryl $\beta$-glucosidases. These isozymes can be investigated in further study by analysis of $\mathrm{N}$-terminal sequences and cloning of their genes. BGL-A1 and BGL-A2 showed many similar enzymatic properties, such as optimum $\mathrm{pH}$, temperature, thermostability, and $K_{\mathrm{m}}$ values for $p N P G$, whereas the enzymatic properties of BGL-A3 differed from those of the other two enzymes. The three $\beta$-glucosidases effectively hydrolyzed tilianin, a flavonoid glycoside, and the reaction products showed inhibitory activity against MAO-A. The results suggest that hydrolysis of the flavone glycoside by these enzymes offers a means of improving inhibition of the pharmaceutical enzyme.

\section{Acknowledgments}

This paper was supported by the Sunchon National University Research Fund in 2016.

\section{Conflict of Interest}

The authors have no financial conflicts of interest to declare. 


\section{References}

1. Ketudat Cairns JR, Esen A. 2010. $\beta$-Glucosidases. Cell. Mol. Life Sci. 67: 3389-3405.

2. Sørensen A, Lübeck M, Lübeck PS, Ahring BK. 2013. Fungal beta-glucosidases: a bottleneck in industrial use of lignocellulosic materials. Biomolecules 3: 3612-3631.

3. Patchett ML, Daniel RM, Morgan HW. 1987. Purification and properties of a stable beta-glucosidase from an extremely thermophilic anaerobic bacterium. Biochem. J. 243: 779-787.

4. Ahmed A, Nasim Fu-H, Batool K, Bibi A. 2017. Microbial $\beta$-glucosidase: sources, production and applications. J. Appl. Environ. Microbiol. 5: 31-46.

5. Krisch J, Takó M, Papp T, Vágvölgyi C. 2010. Characteristics and potential use of $\beta$-glucosidases from Zygomycetes, pp. 891-896. In Méndez-Vilas A (ed.). Current Research, Technology and Education Topics in Applied Microbiology and Microbial Biotechnology. Formatex Research Center, Badajoz, Spain.

6. Singh G, Verma AK, Kumar V. 2016. Catalytic properties, functional attributes and industrial applications of $\beta$ glucosidases. 3 Biotech 6: 3 .

7. Tokpohozin SE, Fischer S, Sacher B, Becker T. 2016. $\beta$-DGlucosidase as "key enzyme" for sorghum cyanogenic glucoside (dhurrin) removal and beer bioflavouring. Food Chem. Toxicol. 97: 217-223.

8. Cao P, Wang L, Wang Y, Zhou N, Chen Y. 2015. Alkalitolerant $\beta$-glucosidase produced by newly isolated Aspergillus fumigatus WL002 from rotten wood. Int. Biodeterior. Biodegradation 105: 276-282.

9. Sørensen A, Ahring BK, Lübeck M, Ubhayasekera W, Bruno KS, Culley DE, et al. 2012. Identifying and characterizing the most significant $\beta$-glucosidase of the novel species Aspergillus saccharolyticus. Can. J. Microbiol. 58: 1035-1046.

10. Thongpoo P, Srisomasap C, Chokchaichamnankit D, Kitpreechavanich V, Svasti J, Kongsaeree PT. 2014. Purification and characterization of three $\beta$-glycosidases exhibiting high glucose tolerance from Aspergillus niger ASKU28. Biosci. Biotechnol. Biochem. 78: 1167-1176.

11. Asha P, Jose Divya, Bright Singh IS. 2016. Purification and characterisation of processive-type endoglucanase and $\beta$ glucosidase from Aspergillus ochraceus MTCC 1810 through saccharification of delignified coir pith to glucose. Bioresour. Technol. 213: 245-248.

12. Kudo K, Watanabe A, Ujiie S, Shintani T, Gomi K. 2015. Purification and enzymatic characterization of secretory glycoside hydrolase family 3 (GH3) aryl $\beta$-glucosidases screened from Aspergillus oryzae genome. J. Biosci. Bioeng. 120: 614-623.

13. Yan FY, Xia W, Zhang XX, Chen S, Nie XZ, Qian LC. 2016. Characterization of $\beta$-glucosidase from Aspergillus terreus and its application in the hydrolysis of soybean isoflavones. J. Zhejiang Univ. Sci. B 17: 455-464.

14. Chang KH, Jo MN, Kim KT, Paik HD. 2012. Purification and characterization of a ginsenoside $\mathrm{Rb}(1)$-hydrolyzing $\beta$ glucosidase from Aspergillus niger KCCM 11239. Int. J. Mol. Sci. 13: 12140-12152.

15. Oh JM, Lee JP, Baek SC, Kim SG, Jo YD, Kim J, et al. 2018. Characterization of two extracellular $\beta$-glucosidases produced from the cellulolytic fungus Aspergillus sp. YDJ216 and their potential applications for the hydrolysis of flavone glycosides. Int. J. Biol. Macromol. 111: 595-603.

16. Zang X, Liu M, Wang H, Fan Y, Zhang H, Liu J, et al. 2017. The distribution of active $\beta$-glucosidase-producing microbial communities in composting. Can. J. Microbiol. 63: 998-1008.

17. Yan FY, Xia W, Zhang XX, Chen S, Nie XZ, Qian LC. 2016. Characterization of $\beta$-glucosidase from Aspergillus terreus and its application in the hydrolysis of soybean isoflavones. J. Zhejiang Univ. Sci. B 17: 455-464.

18. Park DJ, Lee YS, Choi YL. 2013. Characterization of a coldactive $\beta$-glucosidase from Paenibacillus xylanilyticus KJ-03 capable of hydrolyzing isoflavones daidzin and genistin. Protein J. 32: 579-584.

19. Yang X, Ma R, Shi P, Huang H, Bai Y, Wang Y, et al. 2014. Molecular characterization of a highly-active thermophilic $\beta$ glucosidase from Neosartorya fischeri P1 and its application in the hydrolysis of soybean isoflavone glycosides. PLoS One 9: e106785.

20. Shin KC, Nam HK, Oh DK. 2013. Hydrolysis of flavanone glycosides by $\beta$-glucosidase from Pyrococcus furiosus and its application to the production of flavanone aglycones from citrus extracts. J. Agric. Food Chem. 61: 11532-11540.

21. Lee HW, Ryu HW, Baek SC, Kang MG, Park D, Han HY, et al. 2017. Potent inhibitions of monoamine oxidase $\mathrm{A}$ and $\mathrm{B}$ by acacetin and its 7-O-(6-O-malonylglucoside) derivative from Agastache rugosa. Int. J. Biol. Macromol. 104: 547-553.

22. Cho KM, Kwon EJ, Kim SK, Kambiranda DM, Math RK, Lee $\mathrm{YH}$, et al. 2009. Fungal diversity in composting process of pig manure and mushroom cultural waste based on partial sequence of large subunit rRNA. J. Microbiol. Biotechnol. 19: 743-748.

23. Zhang Z, Schwartz S, Wagner L, Miller W. 2000. A greedy algorithm for aligning DNA sequences. J. Comput. Biol. 7: 203-214.

24. Morgulis A, Coulouris G, Raytselis Y, Madden TL, Agarwala R, Schäffer AA. 2008. Database indexing for production MegaBLAST searches. Bioinformatics 24: 1757-1764.

25. Jeong YS, Na HB, Kim SK, Kim YH, Kwon EJ, Kim J, et al. 2012. Characterization of Xyn10J, a novel family 10 xylanase from a compost metagenomic library. Appl. Biochem. Biotechnol. 166: 1328-1339.

26. Bradford MM. 1976. A rapid and sensitive method for the quantitation of microgram quantities of protein utilizing the principle of protein-dye binding. Anal. Biochem. 72: 248-254.

27. Laemmli UK. 1970. Cleavage of structural proteins during the assembly of the head of bacteriophage T4. Nature 227: 680-685. 
28. Phuong ND, Jeong YS, Selvaraj T, Kim SK, Kim YH, Jung KH, et al. 2012. Production of $\mathrm{XynX}$, a large multimodular protein of Thermoanaerobacterium sp., by protease-deficient Bacillus subtilis strains [corrected], Appl. Biochem. Biotechnol 168: 375-382. Appl. Biochem. Biotechnol. 168: 1349-1350.

29. Miller GL. 1959. Use of dinitrosalicylic acid reagent for the determination of reducing sugar. Anal. Chem. 31: 428-436.

30. Shin ES, Yang MJ, Jung KH, Kwon EJ, Jung JS, Park SK, et al. 2002. Influence of the transposition of the thermostabilizing domain of Clostridium thermocellum xylanase (XynX) on xylan binding and thermostabilization. Appl. Environ. Microbiol. 68: 3496-3501.

31. Kwon KS, Kang HG, Hah YC. 1992. Purification and characterization of two extracellular $\beta$-glucosidases from Aspergillus nidulans. FEMS Microbiol Lett. 76: 149-153.

32. Madhu KM, Beena PS, Chandrasekaran M. 2009. Extracellular $\beta$-glucosidase production by a marine Aspergillus sydowii BTMFS 55 under solid state fermentation using statistical experimental design. Biotechnol. Bioprocess Eng. 14: 457-466.

33. Kalyani D, Lee KM, Tiwari MK, Ramachandran P, Kim H, Kim IW, et al. 2012. Characterization of a recombinant aryl $\beta$-glucosidase from Neosartorya fischeri NRRL181. Appl. Microbiol. Biotechnol. 94: 413-423.

34. Li X, Zhao J, Shi P, Yang P, Wang Y, Luo H, et al. 2013.
Molecular cloning and expression of a novel $\beta$-glucosidase gene from Phialophora sp. G5. Appl. Biochem. Biotechnol. 169: 941-949.

35. Plant AR, Oliver JE, Patchett ML, Daniel RM, Morgan HW. 1988. Stability and substrate specificity of a $\beta$-glucosidase from the thermophilic bacterium Tp8 cloned into Escherichia coli. Arch. Biochem. Biophys. 262: 181-188.

36. Gong G, Zheng Z, Liu H, Wang L, Diao J, Wang P, et al. 2014. Purification and characterization of a $\beta$-glucosidase from Aspergillus niger and its application in the hydrolysis of geniposide to genipin. J. Microbiol. Biotechnol. 24: 788-794.

37. Pei X, Zhao J, Cai P, Sun W, Ren J, Wu Q, et al. 2016. Heterologous expression of a GH3 $\beta$-glucosidase from Neurospora crassa in Pichia pastoris with high purity and its application in the hydrolysis of soybean isoflavone glycosides. Protein Expr. Purif. 119: 75-84.

38. Yan Q, Zhou XW, Zhou WX, Li W, Feng MQ, Zhou P. 2008. Purification and properties of a novel $\beta$-glucosidase, hydrolyzing ginsenoside $\mathrm{Rb} 1$ to $\mathrm{CK}$, from Paecilomyces Bainier. J. Microbiol. Biotechnol. 18: 1081-1089.

39. Lin F, Guo X, Lu W. 2015. Efficient biotransformation of ginsenoside $\mathrm{Rb} 1$ to $\mathrm{Rd}$ by isolated Aspergillus versicolor, excreting $\beta$-glucosidase in the spore production phase of solid culture. Antonie Van Leeuwenhoek 108: 1117-1127. 